\title{
The Nature of Custom: Legal Science and Comparative Legal History in Blackstone's Commentaries
}

\author{
ANDREW J. CECCHINATO
}

È grande errore parlare delle cose del mondo indistinctamente et absolutamente et, per dire così, per regola; perché quasi tucte hanno distinction et exceptione per la varietà delle circumstantie, le quali non si possono fermare con una medesima misura: et queste distinctione et exceptione non si truovano scripte in su' libri, ma bisogna le insegni la discretione.

Francesco Guicciardini, Ricordi

When men comfort themselves with philosophy, 'tis not because they have gott two or three sentences, but because they have digested those sentences, \& made them their owne, so upon the matter, philosophy is nothing but discretion.

John Selden, Table-Talk

Seen at an angle, William Blackstone's Commentaries are as much concerned with ordering English law as they are intent on comparing and reconciling its principles to the whole of legal experience. ${ }^{1}$ This secondary and perhaps inconspicuous concern may be illuminated by

1 The last few years have seen a resurging interest in the work of William Blackstone led by the scholarly efforts of Wilfrid Prest. See W. Prest, William Blackstone: Law and Letters in the Eighteenth Century (Oxford 2008); along with W. Prest (ed.), Blackstone and his Commentaries: Biography, Law, History (Oxford and Portland, OR, 2009); W. Prest (ed.), Re-interpreting Blackstone's Commentaries: A Seminal Text in National and International Contexts (Oxford and Portland, OR, 2014); W. Prest (ed.), Blackstone and his Critics (Oxford and Portland, OR, 2018).

The research presented in this article has been supported by the European Research Council, through the Advanced grant n. 740611' 'Civil law, common law, customary law: consonance, divergence and transformation in Western Europe from the late eleventh to the thirteenth centuries' (see http://clicme.wp.st-andrews.ac.uk). 
Blackstone's reading of John Selden. ${ }^{2}$ Blackstone was indeed an attentive reader of Selden and gathered in the margin of the Commentaries references to most of his works. More importantly, Blackstone was a reader who shared Selden's belief in the fundamental unity of legal experience. This may appear counterintuitive, as both Selden and Blackstone saw in the teeming variety of law's past and present determinations the chief concern of their historical and jurisprudential scrutiny. But these multiple and, at times, diverging determinations were all informed, sustained and ultimately governed by the same source of juridical authority: will. The will that Selden and Blackstone had in mind was neither empty nor arbitrary. It coincided, first and foremost, with the wisdom of God's will. It had been God's everlasting word which had dictated the principles of natural law, and it was His will that acted as the supreme authority binding the human determination of positive laws. Thus, Selden and Blackstone shared a voluntarist conception of customary and statutory norms that rested on theological premises, according to which human laws translated, actualised and detailed into a multitude of historical bodies of law, the 'eternal' and 'immutable laws of good and evil'. ${ }^{3}$ Because of this, both belonged to a scholarly tradition that had assigned to jurisprudence the triple office of acknowledging historical differences between discrete bodies of law; of comparing the legal implications of these variations; and of reconciling - through comparative history and the invocation of first principles - the singular instances of the law to the whole of legal experience. ${ }^{4}$

${ }^{2}$ See M. Lobban, A Treatise of Legal Philosophy and General Jurisprudence, vol. VIII: A History of the Philosophy of Law in the Common Law World, 1600-1900 (Dordrecht, 2007), 100

${ }^{3}$ W. Blackstone, Commentaries on the Laws of England, Book I: The Rights of Persons, eds. W. Prest and D. Lemmings (Oxford, 2016), [Int., sec. 2], 34. See also H. J. Berman, Law and Revolution, II: The Impact of Protestant Reformations of the Western Legal Tradition (Cambridge, MA, 2003), 245-8.

${ }^{4}$ See G. Capograssi, Il problema della scienza del diritto (Milan, 1962), 220-1: 'the role of science in the history of law is precisely this: to make such history possible, to make the history of legal experience possible. Law's action, which tends to lose itself in the mixture of reality and in the inexhaustible diversity of history, finds in science the strength that, not only fixes its essence in corresponding concepts, but proves that such diversity is always predicated on a profound unity of life, principles and needs, which explain and support the innumerable differences of historical forms. Science welcomes the differences of history as differences, but retraces them to the unity of experience, it gives them a precise meaning: illuminating and revealing them through the inherent conception that resides within experience and from which diversities arise; ... it therefore discovers the profound juridical meaning that diversities possess. Hence, it can be argued that science makes history possible, 
These seem to be the common premises that united Selden and Blackstone in their investigation of legal history and, by extension, elevated history to the summit of English legal education. When seen from this perspective, it was the legal interpretation of history that preserved, explained and reconciled the singularities of law. ${ }^{5}$ Not only had it been in the course of history that the multiple sources of English law had emerged and combined - often at a high price - in one organic body, it had also been history itself that, in time, had been recognised as the crucial source of the English legal tradition. Hence, one of the central problems raised in Blackstone's Commentaries is that of determining the authority of the English legal tradition and of ascertaining the nature of its primary normative source: custom. ${ }^{6}$

Blackstone himself had invoked the authority of Selden at the very beginning of his examination of custom, and sided with his understanding of its nature, over the older one presented by Sir John Fortescue, and more recently restated by Sir Edward Coke:

Our antient lawyers, and particularly Fortescue, insist with abundance of warmth, that these customs are as old as the primitive Britons, and continued down, through the several mutations of government and inhabitants, to the present time unchanged and unadulterated. This may be the case as to some; but in general, as Mr Selden in his notes observes, this assertion must be understood with many grains of allowance; and ought only to signify, as the truth seems to be, that there never was any formal exchange of one system of laws for another: though doubtless by the intermixture of adventitious nations, the Romans, the Picts, the Saxons, the Danes, and the Normans, they must have insensibly introduced and incorporated many of their own customs with those that were before established: thereby in all probability improving the texture and wisdom of the whole, by the accumulated wisdom of divers particular countries. $^{7}$

because science is entrusted with the office of placing, affirming, remembering the profound continuity of life and the course that, beneath all the leaps, the precipices and the discontinuities of reality, legal history reveals.' All translations are my own.

${ }^{5}$ See M. D. Couzinet, Histoire et méthode a la Renaissance. Une lecture de la Methodus ad facilem historiarum cognitionem de Jean Bodin (Paris, 1996), 104. Bodin's historical comparativism had significant consequences for the history of legal thought beyond the Channel, see D. Quaglioni, 'Le comparatism historique d'Alberico Gentili (1522-1608)', Revue des Sciences Philosophiques et Théologiques, 102 (2018), 251-62.

${ }^{6}$ See A. Cromartie, 'The Idea of Common Law as Custom', in A. Perreau-Saussine and J. B. Murphy (eds.), The Nature of Customary Law: Legal, Historical and Philosophical Perspectives (Cambridge, 2007), 203-27, along with the bibliography cited therein.

7 Blackstone, Commentaries, I. 51. 
The organic nature of English legal history summarised in this passage would seem sufficient to justify the comparative outlook that Blackstone was to adopt in his treatment of general custom. And yet, though the Commentaries repeated the trope according to which customs had originally been oral and ancestral habits retained by memory and usage alone, the customs that Blackstone identified as actual sources of English law had lost all ancestral qualities, and belonged instead to a highly formalised body of recorded customary law. ${ }^{8}$ Moreover, Blackstone presented a sophisticated interpretation of English customary law that depended on the systematic use of external authorities, which he drew from a comparative history of European sources of law. ${ }^{9}$

Building on these considerations, I would like to propose a twofold argument. First, I would like to suggest that the place in which comparative legal history played its role in the Commentaries was in the relationship between text and authority. This at least seems to be the case judging from Blackstone's treatment of general custom, where sensitive questions concerning the legal nature of custom were addressed by including in the Commentaries' analysis comparative references to external authorities. The careful placement of these external points of reference offered to the student of English law valuable signposts and lent a greater sense of direction to Blackstone's investigation. But it also fulfilled a subtler purpose: it shaped the interpretation of English law and transformed the comparative history of European legal sources into one of the interpretative means by which the Commentaries organised English law. To put it succinctly, comparison supplemented the law, not because Blackstone considered external authorities to be formally normative and coercive, but because these authorities belonged to the substance of legal thought as it unfolded 'in the seamless web of legal history', thus proving vital in guiding his interpretation of English law. ${ }^{10}$ Accordingly, and here is my second point, the effect of Blackstone's use of comparative

${ }^{8}$ It is useful to keep in mind, while reading Blackstone, the traditional concerns raised, in the so-called Romanist tradition, around custom and customary law. A compelling illustration of them is provided in L. Mayali, 'La coutume dans la doctrine Romaniste au Moyen age', in J. Gilissen (ed.), La coutume - Custom, 2 vols. (Brussels, 1990), vol. II, $11-31$.

${ }^{9}$ By using these authorities, even as mere comparators, Blackstone showed them to be perhaps external to the norm he was interpreting, but not to the tradition in which he was operating.

10 J. Hudson, The Oxford History of the Laws of England, Volume 2: 871-1216 (Oxford, 2012), 14. 
legal history seems to have gone beyond simply clarifying contentious points of the law. It would seem to have uncovered the inner reasons of English laws, the reasons why history had given to these municipal norms their particular shape. And in doing so, it looks as if Blackstone's comparative perspective drew, out of the history of these norms, those first principles which the ascending degrees of systematic thinking present in the Commentaries deemed responsible for integrating the municipal laws of the English kingdom into a coherent body of internal law, and this body of internal law into the larger whole of the European legal tradition. Hence, my intent is to verify whether it might have been through such a process of comparison and integration that the Commentaries sought to understand the historical singularities of English law and dialectically reconcile them to the whole of legal experience.

The sedes materiae of Blackstone's treatment of customary law was the third section of his general introduction to the Commentaries. This section presents a systematic account of English legal sources and is opened, after a series of preliminary remarks on the fundamental partition between sources of English law, by a discussion on customs. In testing the argument that I have just outlined, I will follow Blackstone's comparative treatment of general custom and consider in turn the three defining issues he examined to determine its nature: supremacy, relation to case law and constitutional authority.

General customs known as Common law stood supreme among the sources of English law. ${ }^{11}$ They were 'the first ground and chief corner stone of the laws of England'. ${ }^{12}$ As such, Blackstone considered them to be among the core embodiments of English sovereignty. Yet, the exact scope of their supremacy and the normative rationale justifying their preeminence were complex issues that engaged Blackstone's labours throughout crucial portions of the Commentaries. This is why I will begin by drawing together the several strands of an argument developed by Blackstone to explore and explain the legal foundation of the Common law's primacy.

Within the municipal system of law's written and unwritten sources, Common law took precedence over unwritten laws that were either local or had acquired authority by virtue of their incorporation into English law. Blackstone called these latter norms 'particular laws' and included amongst them 'the civil and canon laws', i.e. that body of the utrumque

11 See Blackstone, Commentaries, I. [Int., sec. 3] 51.

12 Ibid., I. [Int. sec. 3] 55. 
ius, or ius commune, that had been adopted in England 'by custom' and 'used only in certain peculiar courts and jurisdictions'. ${ }^{13}$ It was primarily in relation to this body of law that the Common law enjoyed preeminence.

Determining the relationship, within the English legal order, between the Common law and the ius commune was certainly not a new challenge. Unsurprisingly, therefore, Blackstone addressed it according to the settled opinion of English jurisprudence and adopted the view that had been restated only a century earlier by Matthew Hale: 'all the strength that either the papal or imperial laws have obtained in this realm, or indeed in any other kingdom in Europe', wrote Blackstone, 'is only because they have been admitted and received'. ${ }^{14}$ As so often happens in the Commentaries, Blackstone gathered and abridged in a short turn of phrase the condensed outcome of a vast doctrinal debate. Beneath this statement lay, in fact, a principle that had been both developed and transformed over several centuries in a Europe-wide conversation. Well before the eighteenth century, this principle had been invoked to justify the independence of national laws and establish, by extension, their superiority over the ius commune. By the time Blackstone reverted to its authority, its use had become virtually ubiquitous, as jurists across Europe found in the creative consistency to its underlying rationale the explanation needed to establish a proper hierarchy of sources. Moreover, because of its foundational character, Blackstone never tired of restating it, so the principle reappeared countless times throughout the Commentaries. I would argue, however, that its most important formulation occurred in book 1 , chapter 7 , for it was here that Blackstone explicitly identified this European maxim and retraced its municipal authority to a correspondingly English source. The identification came amid Blackstone's analysis of royal prerogatives and was meant to explain why two Tudor statutes, enacted during the Reformation - 24 Hen. VIII c. 12 and 25 Hen. VIII c. 28 - had styled the English Crown as 'imperial' and the English kingdom as an 'empire':

13 Ibid., I. [Int., sec. 3] 58. After discussing the history and authority of the Civil and Canon laws, highlighting the particular vicissitude of their English reception and usage, Blackstone further observed: 'There are four species of courts in which the civil and canon laws are permitted under different restrictions to be used. 1 . The courts of the archbishops and bishops and their derivative officers ... 2. The military courts. 3 . The courts of admiralty. 4. The courts of the two universities'. See ibid., I. [Int., sec. 3] 62.

14 Ibid., I. [Int., sec. 3] 59. See M. Hale, The History of Common Law in England, ed. C. M. Gray (Chicago, IL and London, 1971), 18-20. 
Formerly there prevailed a ridiculous notion, propagated by the German and Italian civilians, that an Emperor could do many things which a king could not, (as the creation of notaries and the like) and that all kings were in some degree subordinate and subject to the Emperor of Germany or Rome. The meaning therefore of the legislature, when it uses these terms of empire and imperial, and applies them to the realm of England, is only to assert that our king is equally sovereign and independent within these his dominions, as any Emperor is in his empire; and owes no kind of subjection to any other potentate upon earth. ${ }^{15}$

There is an irresistible concinnitas to this passage that belongs only to Blackstone at his finest. Nothing stands in between text and authority. The two seamlessly blend together and coalesce in their illustration of the inner life of English law. Their harmonisation is such an essential part of Blackstone's legal reasoning that the presence of one of the most pervasive and consequential maxims of the ius commune goes almost unnoticed and appears to be integral - because Blackstone shows that it is - to the municipal logic of English law. ${ }^{16}$ And yet, the passage does indeed select the principle according to which 'rex superiorem non recognoscens, in regno suo est imperator' ('the king, recognising no superior, is emperor in his kingdom') as the axis on which Blackstone hinged the legal justification of English sovereignty. This justification was essential to determining the proper order of sources under English law, since it was because England was subject to none that its main body of law stood supreme. ${ }^{17}$

Despite its integration into the text, however, the maxim still needed to be adequately grounded in the English legal tradition. Blackstone did so in the second edition of the Commentaries, where he completed the passage just quoted by adding a footnote. This addition allowed him to cite the rex in regno suo maxim according to the formula that had been supposedly spoken in the eleventh century by William II and later recorded by the thirteenth-century Benedictine monk Matthew Paris in

15 Blackstone, Commentaries, I. [Ch. 7] 157. See also the now classic article by W. Ullmann, 'This Realm of England is an Empire', Journal of Ecclesiastical History, 30 (1979), 175-203.

${ }^{16}$ Harmony has been recently seen as the key to both Blackstone's diction and his doctrine. See K. D. Temple, Loving Justice: Legal Emotions in William Blackstone's England (New York, 2019).

17 Because it stood supreme, it was this body of law that limited sovereign power. The juristic significance of this interpretation is highlighted in K. Pennington, The Prince and the Law, 1200-1600: Sovereignty and Rights in the Western Legal Tradition (Berkeley, CA, 1993), 101. 
his Chronica majora: 'Rex allegavit, quod ipse omnes libertates haberet in regno suo, quas imperator vendicabat in imperio' ('The king alleged that he should possess all the rights in his kingdom as the emperor was claiming in his empire'). ${ }^{18}$ By so doing, Blackstone offered evidence that this principle had enjoyed municipal authority even before it had been adopted by the two Tudor statutes and could indeed be traced back to the earliest days of the Common law. At that time, the formula had enjoyed an extraordinary success throughout Europe and continued to designate, well into the heart of modernity, that supreme synthesis of powers later known by the name of sovereignty. Over time, however, the implications that jurists drew from the formula became increasingly radical. Francesco Calasso has so effectively summarised them that it is worth translating his observations in full:

[A]t first [the formula] had merely meant to say this: those powers that according to the spirit of the time belonged to the emperor, as dominus mundi, over the universal empire had to be recognized as belonging to each free monarch within the limits of his own kingdom. It did not take long for the formula to extend its meaning far beyond the circle of free kings and encompass within its orbit all the particular jurisdictions that, by holding within themselves the innermost reason of their individual life, possessed the powers necessary to develop it. Moreover, the formula did not fail to reproduce its effects on the order of law's sources by overturning the original notion of an absolute ius commune, ruling out all inconsistent expressions of particular law, to affirm in its place the primacy of the ius proprium, now understood to be the spontaneous and free therefore legitimate - expression of life running through individual jurisdictions, that effectively assigned to the ius commune only the subsidiary function of supreme regulator and coordinator. ${ }^{19}$

Now, this line of reasoning seems to explain why Blackstone reverted so decisively, in his interpretation of English sovereignty, to a maxim belonging to a world that had long since died out: because it had been the jurisprudence developing around that maxim that had prepared and accelerated an inversion of authority that had first overturned the relationship between the ius commune and the iura propria, and then pressed

18 Blackstone, Commentaries, I. 347. Insights concerning the legal learning of Matthew Paris may be gathered from M. T. Clanchy, 'Did Henry III Have a Policy?', History, 53 (1968), 203-16.

19 F. Calasso, I glossatori e la teoria della sovranità (Milan, 1957), 23. See also B. Tierney, 'Some Recent Works on the Political Theories of the Medieval Canonists', Traditio, 10 (1954), 612-19. 
legal thought to develop a new conception of municipal law. By proving that the rex in regno suo principle had continuously operated in English law, and that the combined effect of those forces animating its legal and historical vitality had been to elevate municipal law above the ius commune, Blackstone was trying to establish a systemic point of connection between the history of English law, the supremacy of its primary source and the scientific authority deposited in the European legal tradition. After all, this conclusion was an easy one to draw since it had been widely maintained by modern jurisprudence. And Blackstone knew it, if for no other reason than because it had been confirmed by his main source on the matter: John Selden. ${ }^{20}$ Along with Hale, Selden guided Blackstone in his exploration of the Common law's preeminence and provided him with the references to crucial normative and doctrinal sources quoted in this section of the Commentaries. Not only did the references to Paris and the two Reformation statutes come from Selden, but it had been Selden who had explained the European scope and English authority of the rex in regno suo principle in his major work on comparative public law, Titles of Honor. Rich and subtle as it is, Selden's long review of the matter deserves extensive quotation. ${ }^{21}$

${ }^{20}$ See Blackstone, Commentaries, I. [Ch. 7] 157, where Blackstone expressly references Selden's Titles of Honor, book I, chapter 2.

${ }^{21}$ See J. Selden, Titles of Honor, 2nd edn (London, 1631), 18-23. During his lifetime, Selden compiled two editions of Titles of Honor. See G. J. Toomer, John Selden: A Life in Scholarship, 2 vols. (Oxford 2009), vol. I, 126-68. The first edition was published in 1614, the second in 1631. I am inclined to believe that, while discussing the principle rex... in regno suo est imperator, Blackstone had in mind and cited the second edition of Titles of Honor rather than the first. I base this assumption of the similarity of Blackstone's language with the relevant passages in Selden. A more cogent reason is that, like Selden, Blackstone too called Italian and German civilian doctrines supporting the superior lordship of the emperor 'ridiculous'. See Blackstone, Commentaries, I. 157. The same expression recurred in the 1631 edition of Titles of Honor and specifically in the title given to book I, chapter 2, par. 6: 'The Supremacy of those and other Kings free from the subjection of the Empire of Rome against the common, but ridiculous, opinion of many Civilians.' Unless I am mistaken, this qualification does not appear in the earlier 1614 edition, which - in any case - does not have titled paragraphs. A comparison between the two versions is highly interesting. Let me note, incidentally, that while the 1614 version seems more interested in refuting the notion of dominus mundi put forth by Bartolus somewhat repeating the same arguments that had been outlined earlier by 'Tramontan Doctors' such as Bodin (Republique, I, 9) and that would eventually be reprised, eleven years after the first publication of Titles of Honor, by Grotius (De iure belli ac pacis, II, 22, 13) - the 1631 version was more focused on 'discreeter' civilian jurisprudence. Here, although Selden did indeed criticise the more conservative opinions of jurists like Marta, he also emphasised and relied on the doctrines of 'some more of the discreeter Civilians', 
Although Selden was perfectly aware that emperors in both the East and West of Europe had claimed the title for themselves alone, excluding its application to all lesser rulers, he had no hesitation in recognising that 'Kings of other Nations' had also adopted the same title 'as no less proper to their own greatness'. ${ }^{22}$ The 'Kings of England', for instance, had 'justly used' the title of emperor, 'and that from antient Ages.'. ${ }^{23}$ The claim was supported by precise historical evidence: 'For our Edgar frequently in his Charters called himself Albionis \& Anglorum Basileus. ${ }^{24}$ This certainly did not represent an isolated case, for even though the title was 'not directly used in the following times, yet the substance of it was sufficiently challenged in that of William the Second, when he so confidently told Archbishop Anselm that ipse omnes libertates habebat in Regno suo quas Imperator vindicabat in Imperio, as the words in Matthew Paris. ${ }^{25}$ At this point, Selden moved briskly forward and, building on these historical premises, observed that

also under King Henry VIII the whole Parliament conceived, and so expressed themselves [Selden's marginal note: 24 Hen. VIII c. 12, 25 Hen. VIII c. 21] that by diverse and sundry old authentique Histories and Chronicles it is manifestly declared and expressed that this Realm of England is an Empire and so hath been accepted in the World, governed by some supreme Head and King, having dignity and Royal Estate of the Imperial Crown of the same. ${ }^{26}$

Having thus proven that the title of emperor had been in use in the kingdom of England, Selden moved to similar investigations concerning the kingdoms of France and Spain, among others. Now, once his historical evidence had been collected, Selden began considering its legal significance: ${ }^{27}$

Neither is the use of this Title of Emperor in the stile of other Princes any injury to the Emperor of Germany, who is commonly so known by that

such as 'Albericus Gentilis', who had recognised the full majesty of free kings. See Selden, Titles of Honor ${ }^{2}$, 23. See also J. Selden, Titles of Honor, 1st edn (London, 1614), 26; J. Bodin, Les six livres de la République (Paris, 1583), 189; and H. Grotius, De iure belli ac pacis, ed. B. J. A. de Kanter-van Hettinga Tromp, R. Feenstra, and C. E. Persenaire (Aalen, 1993), 560.

22 Selden, Titles of Honor ${ }^{2}, 18$.

${ }^{23}$ Ibid., 18.

24 Ibid., 18.

25 Ibid., 19.

${ }^{26}$ Ibid., 19 (italics in original).

27 Ibid., 20-23. 
name as if it were only proper to him. Indeed divers Civilians, especially of Italy and Germany, which profess the old Laws of Rome, tell us, that the Emperor is at this day, of right, Lord of the Whole World or Earth ... But it is most clear that neither anciently nor at this day there is any such title, as Lord of the whole World, really due to him, and that diverse other Princes, as the Kings of England, Scotland, France, Spain, beside others, have their supremacy, acknowledging no Superior but God himself, and may every way as justly (as the Emperor of Rome) be stiled Emperors, or by any other name which expresses the fullest height of Honor and Dignity.

\section{Why? Because}

besides the States of Asia, Afrique, and America, the greatest Kings of Europe have from many Ages been absolutely supreme, without any kind of colour of subjection to the Empire. As for the Kings of Spain, those great Lawyers of that Country, Valdesius, Burgo de Paz, Diego Perez, Ferdinando Vasques, Convaruvias, Hieronymo de Zevallos, and such more make it clear, that the King of Spain is from ancient right free from all colour of this kind of subjection. The same in the Kingdom of France, is justified by those French Lawyers, Bodin, Chassanaeus, Bignon, Carolus de Grassaliis, and divers others. ... But for this matter (which is indeed of itself most clear) whosoever shall be troubled with the obvious opinions and arguments of the Civilians, as especially of that Neopolitan Marta, Zoannettus, and the like, who attributed all temporal supremacy to the Empire of Germany, as it hath succeeded to Rome, let them more fully by particulars satisfie themselves out of those learned and judicious Lawyers that live under the Empire, Henningius, Arnisaeus, and Bernardus Zieritzius, besides the Spanish Zevallos, Albericus Gentilis, and some more of the discreeter Civilians, who have both singularly disputed this question, and have also vindicated the rights of supreme Majesty to other Kings of Europe, nothing at all derogating from the true Dignity of the Empire.

This entire passage elaborated a specific interpretation of the rex in regno suo principle, which turned on its head the traditional understanding of imperium. For the jurists belonging to the long tradition of the ius commune, the belief in the universal jurisdiction of the empire amounted to the belief in the existence of a supreme principle of justice embodied by the emperor, who, as the living law, secured the legitimacy of all subordinate acts of power exercised by inferior rulers. Being the pinnacle of justice on earth, the empire was entrusted with the task of securing order in human affairs. Consistently, the Emperor possessed exclusive powers that no lesser ruler could rightly claim as his own. Whereas Blackstone spoke only of the power to establish notaries, the chief power 
that the emperor possessed was the power to enact and interpret laws. However, as the historical institution of the Holy Roman Empire entered into crisis, a number of doctrines elaborated within the very experience of the ius commune began claiming that kings enjoyed, within their necessarily limited jurisdiction, the same powers that were held by the emperor universally. Thus, even within those doctrines that accompanied and sustained the rise of national jurisdictions and the establishment of municipal bodies of law, the paradigm of sovereign power was primarily understood by ascribing to kings the same regalia that had been traditionally recognised to the emperor alone. In this sense, the notion of the emperor became the keystone necessary to define municipal sovereignty well beyond the Middle Ages and the reach of the Holy Roman Empire. ${ }^{28}$

It may seem odd to consider Blackstone's use of the rex in regno suo maxim as an instance of comparative legal history. And yet, although Blackstone's comparison might have been mostly silent in this case, he did acknowledge that English law settled the relationship between its sources and the ius commune exactly like the rest of the contemporary European systems. As he stressed, the notions entertained by English jurists on this point had not been 'singular' in any way:

The Civil and Canon Laws, considered with respect to any intrinsic obligation, have no force or authority in this kingdom; they are no more binding in England than our laws are binding at Rome. But as far as these foreign laws, on account of some peculiar property, have in some particular case, and in some particular courts, been introduced and allowed by our laws, so far they oblige, and no farther: their authority being wholly founded upon that permission and adoption. In which we are not singular in our notions; for even in Holland, where the imperial law is much cultivated and its decisions pretty generally followed we are informed by Van Leeuwen that it receives its force from custom and the consent of the people, either tacitly or expressly given: for otherwise, he adds, we should no more be bound by this law, than by that of the Almains, the Franks, the Saxons, the Goths, the Vandals, and other of the antient nation.' Wherefore, in all points in which the different systems depart from each other, the law of the land takes place of the law of Rome, whether ancient or modern, imperial or pontifical. ${ }^{29}$

${ }^{28}$ See D. Quaglioni, 'Empire et monarchie: aspects du débat juridique', in F. Cremoux and J. L. Fournel (eds.), Idées d'empire en Italie et en Espagne: XIV ${ }^{e}-X V I I^{e}$ siècle (Rouen, 2010), $37-46$.

${ }^{29}$ See Blackstone, Commentaries, I. [Int., sec. 1] 16. 
Yet, Blackstone went frequently beyond silent comparison. And he did so repeatedly when discussing general custom. Let me turn to the second issue concerning customary law examined in the Commentaries and illustrate how Blackstone relied on comparative legal history to explain the authority behind judicial decisions proving the existence of general customs.

Determining the exact relationship between customs and court decisions was among the most pressing problems facing Blackstone in this section of the Commentaries. ${ }^{30}$ Blackstone was writing at a time when customs appeared to be viewed through the lens of two different sources. ${ }^{31}$ On the one hand, there was the source of custom's legal authority. And this source consisted in immemorial usage and general reception. On the other, there were the sources recording and proving the existence of living customs, and these sources were court decisions. While Blackstone certainly did not confuse sources of authority with sources of evidence, he did argue that the latter absolved interpreters from the burden of independently determining the existence of customs: 'judicial decisions', he wrote, 'are the principal and most authoritative evidence ... of the existence of such a custom as shall form part of the common law. ${ }^{32}$ So, at least at first instance, Blackstone seems to have believed that 'judicial consent alone' shaped 'the common law'. ${ }^{33}$ In fact, the Commentaries considered the evidence gathered by case law to be so conclusive that they treated it almost as if it were on the threshold of becoming binding and acknowledged that 'an established rule' compelled one 'to abide by former precedents, where the same points come again in litigation' ${ }^{34}$ But, in so doing, because the Commentaries did not ultimately overcome the distinction between sources of authority and sources of evidence, they did claim that the Common law was based on something more than mere practices settled by professional usage. In fact, Blackstone concluded that, according to the 'doctrine of the law', 'precedents and rules must be followed', given that: 'positive law, fixed and established by custom, which custom is evidenced by judicial

${ }^{30}$ See ibid., I. [Int., sec. 3] 52.

${ }^{31}$ See Cromartie, 'The Idea of Common Law', 222, where the influence of Hale is also discussed.

32 Blackstone, Commentaries, I. [Int., sec. 3] 52.

${ }^{33}$ N. Doe, Fundamental Authority in Late Medieval English Law (Cambridge, 1990), 26.

${ }^{34}$ Blackstone, Commentaries, I. [Int., sec. 3] 52. 
decisions ... can never be departed from by any modern judge without a breach of his oath and the law. ${ }^{35}$

In other words, as weighty as the evidence provided by court decisions might have been, precedents were not in themselves formally binding. ${ }^{36}$ Their authority to determine a custom emanated from elsewhere, and Blackstone identified its source by relying on a comparative analogy: 'We may take it as a general rule, "that the decisions of courts of justice are evidence of what is common law": in the same manner as, in the civil law, what the Emperor had once determined was to serve for a guide for the future. ${ }^{37}$ This clarifying comparison was further integrated by a citation of Justinian's Code, the lex Si imperialis maiestas recorded at C. 1.14.12: 'If the Imperial Majesty has examined a case judicially and has given a decision with the parties at hand, then all judges who are under Our rule shall know that this is a law not only for the case for which it was given, but for all similar cases.' 38

The absence of any commentary other than the few lines quoted above could suggest that the reference was little more than ornamental, and in any case extrinsic to Blackstone's argument. And yet, at closer inspection, the citation of the lex Si imperialis maiestas, along with Blackstone's succinct annotation, coupled with his quest to determine the source conferring authority to judicial assessments of general customary law points to the same essential problem: defining the instances in which qualified forms of legal interpretation enjoyed degrees of normative authority. Even taken by itself, the text of the lex Si imperialis maiestas suggests a proximity between the emperor's power to interpret the law and his power to enact the law. What justifies this proximity is the compulsion by which all magistrates are bound to uphold the same legal principles determined by the emperor while exercising his judicial capacity. Some of the most far-reaching pages of Ennio Cortese's La norma giuridica have been devoted to a detailed investigation of the convergence that early glossators perceived between this interpretatio principis and the

35 Ibid., I. [Int., sec. 3] 53.

36 See N. Duxbury, The Nature and Authority of Precedent (Cambridge, 2008), 8.

37 Blackstone, Commentaries, I. [Int., sec. 3] 53.

38 The Codex of Justinian: A New Annotated Translation with Parallel Latin and Greek Text, ed. and trans. B. W. Frier, 3 vols. (Cambridge, 2016), vol. I, 265. See the quotation in Blackstone, Commentaries, I. 53: 'si imperialis majestas causam cognitionaliter examinaverit, et partibus cominus constitutis sententiam dixerit, omnes omnino judices, qui sub nostro imperio sunt, sciant hanc esse legem, non solum illi causae pro qua producta est, sed et in omnibus similibus'. 
intrinsically similar activity of enacting new law. The overall aim pursued by Cortese has been to prove that, beginning with Irnerius, glossators called upon the legislator to both promulgate the law and illustrate its meaning. Consequently, jurists fashioned 'the two processes of condere and interpretari legem as different manifestations of a unitary phenomenon, or at least as manifestations of the same power': imperium. ${ }^{39}$

By recalling the textual authority at the root of this conception, and drawing an analogy to the authority of court decisions in England, Blackstone seems to have been restating the principle by which certain forms of interpretation were upheld by - and almost seemed to possess a degree of - normative authority. In the case of England, the interpretations of existing customary law sustained by such normative authority were the ones settled by court decisions. Why? Blackstone did not spell out the answer to this question. But the legal reasoning suggested by his particular use of the lex Si imperialis maiestas, as fitted within his overall treatment of the distribution of sovereign power, suggests that he considered the courts to be participants in the English imperium. Courts received, in fact, their jurisdiction directly from the king, so much so that Blackstone described their authority as being delegated. Because of this, once he had established that 'all jurisdiction implies superiority of power', Blackstone adopted a fluvial metaphor, frequently employed in the literature, to link explicitly imperium and iurisdictio. The 'course of justice', he wrote, flows 'in large streams from the king, as the fountain, to his superior courts of record' and is then 'subdivided into smaller channels, till the whole and every part of the kingdom' is 'plentifully watered and refreshed'. ${ }^{40}$

As fountain of all jurisdiction, a title that the king enjoyed as emperor in his own kingdom, the monarch imbued his courts with a degree of iurisdictio and thus allowed them to partake in his imperium. This 'ideology of royal-dominated justice', rooted in the long tradition of English jurisprudence, rendered the office of the courts an emanation

39 E. Cortese, La norma giuridica. Spunti teorici nel diritto comune classico, 2 vols. (Milan, 1962-4), vol. II, 369.

40 W. Blackstone, Commentaries on the Laws of England, Book III: Of Private Wrongs, eds. W. Prest and T. P. Gallanis (Oxford, 2016), [Ch. 4] 20. See also D. Quaglioni, 'Il diritto comune pubblico e le Leggi di Roncaglia. Nuove testimonianze sulla l. Omnis iurisdictio', in G. Dilcher and D. Quaglioni (eds.), Gli inizi del diritto pubblico. L'età di Federico Barbarossa: legislazione e scienza del diritto. Die Anfänge des öffentlichen Rechts. Gesetzbung im Zeitalter Friedrich Barbarossas und das Gelehrte Recht (Bologna and Berlin, 2006), 47-63. 
of sovereign power. ${ }^{41}$ It is this partly implicit (certainly systematic) line of reasoning, I think, that explains Blackstone's comparison between the power of the emperor to set the law while solving disputes and the power of the English courts to provide near-conclusive evidence of existing customary law. Although it is clear that the two powers differed from each other, it is no less clear that Blackstone saw in both of them instances in which qualified forms of legal interpretation demanded to be followed. It is this similarity between the two that made them comparable. And because of their kindred nature, Blackstone appears to presume that the two powers belonged, if not to the same, at least to a conceptually similar form of authority, which would seem to be identifiable in the imperium.

Blackstone drew a further corollary from this conception. He argued that judges were the true 'depositary of the laws' and acted as their 'living oracles' ${ }^{42}$ What he meant was that the law spoke through its interpreters. Judges fulfilled their office by uttering the law and infusing life into its text precisely because it was judicial interpretation that brought to completion the process of law-making. So, it is clear that, in his view, law needed interpretation to operate fully. Montesquieu and Coke before him had argued a similar position, claiming, on the basis respectively of the Digest and of Cicero, that the judges were the true mouths of the law.

In book 11, chapter 6 of De l'esprit des lois, significantly dedicated to 'La constitution d'Angleterre', Montesquieu had stated that judges were 'la bouche qui pronounce les paroles de la loi', the mouth pronouncing the words of the law. ${ }^{43}$ This claim has conventionally been interpreted by Continental readers as meaning that judges should yield to the legislature and merely repeat its prescriptions by mechanically applying them as the major premise of the judicial syllogism. ${ }^{44}$ Yet, this is not the interpretation given by Blackstone to the same notion. For Blackstone, judges could truly act as oracles of the law only if they were able to relate the settlement of the particular disputes entrusted to their cognisance to 'the

${ }^{41}$ J. Hudson, The Formation of the English Common Law: Law and Society in England from King Alfred to Magna Carta, 2nd edn (London and New York, 2018), 201. See also The Treatise on the Laws and Customs of England Commonly Called Glanvill, ed. G. D. G. Hall (Oxford, 1993), 2.

42 Blackstone, Commentaries, I. [Int., sec. 3] 52.

${ }^{43}$ C. Montesquieu, De l'esprit des lois, ed. R. Caillois (Paris, 1951), 404.

${ }^{44}$ For a review of the relevant literature and an attempt to problematise conventional interpretations, see A. Merlino, Interpretazioni di Montesquieu (Foligno, 2018). 
spirit of the laws and the natural foundations of justice'. ${ }^{45}$ Judges, in other words, had 'to show the rational connection between' the particular facts under their scrutiny and 'the whole frame of the universe', ${ }^{46}$ because it was through their judgments alone that the individual statutory and customary rules were related to each other, carried into effect and thus brought into the organic life of the law. Montesquieu himself had stated as much in a lesser known passage of his ceuvre, written while commenting on the first title of the first book of the Digest, namely D. 1.1.8. Here, where the Roman compilation plainly stated 'Nam et ipsum ius honorarium viva vox est iuris civilis' ('indeed, the magistrate law is itself the living voice of Civil law'), Montesquieu wrote: 'Le droit du préteur est la voix du droit civil', by which he meant that it was the casuistic law issued by the praetor that gave voice to the Civil law. ${ }^{47} \mathrm{I}$ do not know whether these claims were made by Montesquieu primarily under the influence of a celebrated Ciceronian maxim, according to which the magistrate was the speaking law, while the law was only a silent magistrate ('magistratum esse legem loquentem, legem autem mutuum magistratum'), or whether they also reflected the influence of the Glossa ordinaria, which Montesquieu could have read in the margin of D. 1.1.8, where he would have found stated that, just as the inclinations of the heart were expressed by the human voice, so the science of Civil law was given voice by the praetor ('ut enim voce exprimitur cordis intentio, ita per praetorem iuris civilis scientia'). ${ }^{48}$ Whatever the case, the point seems to be that for Montesquieu, and certainly for Blackstone, laws as such were merely abstract enactments that could fulfil their purpose and effectively order society only when they had been embodied in the rulings of judges, who were, in turn, the true 'depositary of the laws' precisely because they had sworn to uphold and interpret them according to the principles of justice. ${ }^{49}$ Following the interpretation suggested by Karel Schönfeld, Montesquieu - and I would add Blackstone - drew this notion from

${ }^{45}$ Blackstone, Commentaries, I. [Int., sec. 1] 28.

${ }^{46}$ O. W. Holmes, The Profession of the Law, quoted in H. J. Berman, Law and Revolution: The Formation of the Western Legal Tradition (Cambridge, MA, 1983), vii.

${ }^{47}$ C. Montesquieu, Collectio juris, ed. I. Cox and A. Lewis (Oxford and Naples, 2005), 1.

48 The first hypothesis has been advanced in K. M. Schönfeld, 'Montesquieu et la bouche de la loi: Jacques Ier, Edward Coke et l'antithèse rex-judex', in L. Desgraves and P. Botineau (eds.), La fortune de Montesquieu - Montesquieu écrivain (Bordeaux, 1995), 207-23. More on the jurists as the mouth of the law may be read in E. H. Kantorowicz, The King's Two Bodies (Princeton and London, 2016), 154.

49 Blackstone, Commentaries, I. [Int., sec. 3] 52. 
one of the most important sources in English legal history: Sir Edward Coke's report of Calvin's Case. It is there, in fact, that both Montesquieu and Blackstone could have read that 'books and book-cases' acted as the 'eyes of the law', 'reporters' as the 'ears of the law', 'records of pleadings, cases, and judgments' as the 'stomach of the law', and 'Judges' as the 'mouth of the law (for judex est lex loquens)'. ${ }^{50}$

Looking back to the early modern sources of this conception one is reminded of a richly suggestive passage in Jean Bodin's last chapter of Les six livres de la République. Bringing to an end an insightful meditation on the authority of judicial interpretations, which had taken its cue from the lex opening the same title of Justinian's Code quoted in the abovementioned passage of Blackstone's Commentaries, Bodin argued in words not too dissimilar from the ones chosen by Blackstone himself that 'la droite interpretation de la loy n'est rien autre chose que la loy mesme'. ${ }^{51}$

Let me now conclude by turning to the third and final issue concerning customary law examined in the Commentaries. By relying on comparative legal history to determine why the Common law enjoyed preeminence and normative authority, Blackstone had laid the foundations to explain the constitutional function of English courts. It had been their historical responsibility to secure the living force of general custom. And it was their office to guarantee that general custom remained vital and was not silenced by the law-making authority of Parliament. A similar reductionism was certainly not inconceivable, given Parliament's newly acquired supremacy. But Blackstone was unyielding in his assertion that, even after the Revolution and the establishment of Parliamentary sovereignty, English law maintained its plurality of written and unwritten sources.

This latter consideration did not diminish the centrality of Parliamentary sovereignty. It did, however, highlight that Parliamentary sovereignty did not operate in a vacuum: it was part of a system that balanced written and unwritten law, as well as obedience and interpretation of the law. Preserved within this compound architecture, the ensuing independence of general custom - confirmed, safeguarded, and transformed into Common law by courts - represented for Blackstone one of the characteristic features of English constitutionalism. And it was

\footnotetext{
50 See Schönfeld, 'Montesquieu et la bouche de la loi', 221. See also Calvin's Case, 7 Coke Report 1a.

51 Bodin, République, 1024
} 
this bond between custom and constitutional freedom that urged Blackstone to undertake his final comparison.

The authorities he now called to the stand told a cautionary tale taken from Roman jurisprudence. Their reference was meant to witness the authoritarian contortion that classical Roman law had suffered once its acknowledgement of custom's authority (D. 1.3.32) had been replaced by the proclamation of the emperor's exclusive power to legislate (D. 1.4.1). Thus, the section devoted to custom ended with Blackstone's effort to read Roman law's paradigmatic authorities on the voluntas populi, enacted through custom, and the voluntas principis, enacted through imperial legislation, in light of English constitutional history. ${ }^{52}$ This comparison amounted to a stern warning emphasising how constitutional freedom was guaranteed by the orderly coexistence of diverse sources enacting the separate will of the kingdom's several constituent bodies. As Blackstone acknowledged: it is 'indeed one of the characteristic marks of English liberty, that our common law depends upon custom: which carries this internal evidence of freedom ... that it probably was introduced by the voluntary consent of the people':

The Roman law, as practiced in the time of its liberty paid also a great regard to custom; but not so much as our law: it only then adopting it, when the written law is deficient. Though the reasons alleged in the digest will fully justify our practice, in making it of equal authority with, when it is not contradicted by, the written law. 'For since, says Julianus, the written law binds us for no other reason but because it is approved by the judgment of the people, therefore those laws which the people hath approved without writing ought also to bind every body. For where is the difference, whether the people declare their assent to a law by suffrage, or by a uniform course of acting accordingly?' [D. 1.3.32.] Thus did they reason while Rome had some remains of her freedom; but when the imperial tyranny came to be fully established, the Civil laws speak a very different language. 'Quod principi placuit legis habet vigorem, cum populus ei et in eum omne suum imperium et potestatem conferat [A decision given by the emperor has the force of law, because the people commits to him and in him its own entire authority end power]' says Ulpian [D. 1.4.1]. 'Imperator solus et conditor et interpres legis existimatur [the emperor alone is considered maker and interpreter of the law]' says the code [C. 1.14.12]. And again, 'sacrilegii instar est rescripto principis obviare [it is a sacrilege to oppose the mandate of a prince]' [C. 1.23.5]. ${ }^{53}$

52 See Cortese, La norma giuridica, vol. II, 101-67.

${ }^{53}$ Blackstone, Commentaries, I. [Int., sec. 3] 55. Italics in original. The translations are a combination of my own and those of the editors. 
Although the comparison between English law and classical Roman law immediately revealed how both traditions acknowledged the authority of customary law, it is clear that Blackstone's main interest in this passage was to emphasise the Common law's greater commitment to custom. This commitment was such that it had overturned the relationship between statutory and customary law, fixed in the second century by one of the greatest representatives of classical Roman jurisprudence, Julian. Whereas Roman law resorted to custom only when the written law was 'deficient', English law had established its foundations by asserting the equal authority, but greater antiquity, of customary vis-àvis statutory law. This enhanced position of customary law overturned much more than classical Roman jurisprudence. It toppled the traditional definition of custom offered by the Decretum (c. 5, D. I). Although it is true that the Commentaries did not cite this definition, it would seem nonetheless to have been in the back of Blackstone's mind, since he phrased his examination of the authority enjoyed by customs under Roman law according to its text. In the words of the Decretum, in fact, custom was an expression of law established by usage that enjoyed the same authority of a statute 'cum deficit lex', or as Blackstone would appear to have translated 'when the written law is deficient'. ${ }^{54}$

Blackstone certainly had no need to insist on the relatedness of Canonical and Civil bodies of law. The utrumque ius had become apparently so connatural that even thinking of Roman law historically implied for Blackstone some form of silent association to the later canonical tradition. Nor did Blackstone need to emphasise how important strands of modern jurisprudence had overturned, at least since Machiavelli, the relationship between written law and custom presented in the Decretum. ${ }^{55}$ He could easily retrace and abridge the arguments by which custom had been elevated by sixteenth- and seventeenth-century schools of historical jurisprudence to a position

54 Ibid., I. [Int., sec. 3] 55. In the second edition, Blackstone changed the verb tense to 'was'. See ibid., I. 321. The relevant passage of the Decretum is c. 5, D. I: 'Consuetudo autem est ius quoddam moribus institutum, quod pro lege suscipitur, cum deficit lex.'

55 See N. Machiavelli, 'Discorsi sopra la prima deca di Tito Livio', in N. Machiavelli, Opere, ed. C. Vivanti (Turin 1997), vol. I, 208: 'E dove una cosa per se medesima sanza la legge opera bene, non è necessaria la legge; ma quando quella buona consuetudine manca, è subito la legge necessaria'. See also, N. Machiavelli, Discourses on Livy, eds. H. C. Mansfield and N. Tarcov (Chicago, IL, 1996), 15: 'When a thing works well on its own without the [written] law, the [written] law is not necessary; but when some good custom is lacking, at once the [written] law is necessary.' 
of primacy, and written law had been conversely construed as an essentially integrative source of law.

What Blackstone was instead interested in stressing, what actually lent urgency to an otherwise rather scholastic passage and justified this comparative conclusion, was a double-sided consideration: English law could not be reduced to the law-making authority of Parliament, because however abstractly absolute this authority was, it found its limit in the existence of an independent source of customary law. And customary law carried along with it 'the internal evidence of freedom', guaranteeing as it did that the core of English law had been introduced and maintained 'by the voluntary consent of the people'. ${ }^{56}$

We have reached what I think was the focal point of Blackstone's entire treatment of general custom. It was in order to maintain this constitutional authority of the Common law that the Commentaries engaged in the comparative effort of interpreting general custom in relation to sources drawn from the European legal tradition. If preeminence and normative authority were indeed what gave Common law its standing against the law-making authority of Parliament, then Blackstone's comparative effort can be seen - however secondary it may appear - as essential to his successful treatment of English law as a discrete universality. Far from isolating any of its singular components, Blackstone encouraged their overall comparison by securing the place of each within the larger system of the whole and thus 'abbreviated' the long arch of the European legal tradition in a systematic interpretation of English law. ${ }^{57}$

56 Blackstone, Commentaries, I. [Int., sec. 3] 55.

${ }^{57}$ W. Benjamin, Origin of the German Trauerspiel (Cambridge, Mass., 2019), 27. 